\title{
A Cautious Prometheus? A Few Steps Toward a Philosophy of Design (with Special Attention to Peter Sloterdijk)
}

\author{
Keynote lecture for the Networks of Design* \\ meeting of the Design History Society \\ Falmouth, Cornwall, 3 ${ }^{\text {rd }}$ September 2008 \\ Bruno Latour, Sciences-Po
}

It came to me at a launching party for a Networks of Design meeting - I was struggling to grasp the extent to which the word "design" has been expanded when we were invited to visit an exhibition called "Re-imagining Cornwall"! I was aware that corporations had to be reengineered, natural ecosystems reclaimed, that cities had to be remodelled and wastelands redeveloped. I knew that neighbourhoods had to be beautified and political platforms scripted, and that interiors had to be redecorated and journal layouts restyled. The Cornwall exhibit confirmed that I was indeed on the right track: if entire provinces can be redesigned then the term no longer has any limit.

When I was young, the word design (imported to French from English) meant no more than what we now call "relooking" in French (a good English word that, unfortunately, does not exist in English). To "relook" means to give a new and better "look" or shape to something - a chair, a knife, a car, a package, a lamp, an interior - which would otherwise remain too clumsy, too severe or too bared if it were left only to its naked function. "Design" in this old and limited meaning was a way to redress the efficient but somewhat boring emphasis of engineers and commercial staff. Design occurred by adding a veneer of form to their creations, some superficial feature that could make a difference in taste and fashion. Even if design could be greatly admired, it was always taken as one branch of an alternative: look not only at the function, but also at the design. This dichotomy was true even though the best design was one that, in good modernist fashion (as it did in "functionalism"), approximated function as closely as possible. "Design" was

* I thank Martha Poon for having kindly corrected my English and suggesting many useful changes. 
always taken in this "not only... but also" balance. It was as if there were really two very different ways of grasping an object: one through its intrinsic materiality, the other through its more aesthetic or "symbolic" aspects.

I know this is a very poor rendering of what you now want to mean by "design". (I am well aware that the French use of the word is much more restricted than the Scandinavian or the English one). However, I want to utilize this definition from my youth as a base line from which to fathom the extraordinary career of this term. From a surface feature in the hands of a not-soserious-profession that added features in the purview of much-more-seriousprofessionals (engineers, scientists, accountants), design has been spreading continuously so that it increasingly matters to the very substance of production. What is more, design has been extended from the details of daily objects to cities, landscapes, nations, cultures, bodies, genes, and, as I will argue, to nature itself which is in great need of being re-designed. It is as though the meaning of the word has grown in what logicians refer to as 'comprehension' and 'extension'. First, it has grown in comprehension - it has eaten up more and more elements of what a thing is. Today everyone with an iPhone knows that it would be absurd to distinguish what has been designed from what has been planned, calculated, arrayed, arranged, packed, packaged, defined, projected, tinkered, written down in code, disposed of and so on. From now on, "to design" could mean equally any or all of those verbs. Secondly, it has grown in extension - design is applicable to ever larger assemblages of production. The range of things that can be designed is far wider now than a limited list of ordinary or even luxury goods.

The reason I am interested in the spread in comprehension and extension of the term design is not because of any intimate knowledge of design practice. (I know even less about its history and I hope the many historians of the notion among you will not contradict me too much). Yet I take its expansion as a fascinating tell tale of a change in the ways we deal with objects and action more generally. If it is true as I have claimed that we have never been modern, and if it is true, as a consequence, that "matters of fact" have now clearly become "matters of concern", then there is logic to the following observation: the typically modernist divide between materiality on the one hand and design on the other is slowly being dissolved away. The more objects are turned into things - that is, the more matters of facts are turned into matters of concern - the more they are rendered into objects of design through and through.

If it is true that the present historical situation is defined by a complete disconnect between two great alternative narratives - one of emancipation, detachment, modernization, progress and mastery, and the other, completely different, of attachment, precaution, entanglement, dependence and care - then the little word "design" could offer a very important touch stone for detecting where we are heading and how well modernism (and also postmodernism) has been faring. To put it more provocatively, I would argue that design is one of the terms that has replaced the word "revolution"! To say that everything has to be designed and redesigned (including nature), we imply something of the sort: "it will neither be revolutionized, nor will it be modernized". For me, the word design is a little tracer whose expansion could prove the depth to which we have stopped 
believing that we have been modern. In other words, the more we think of ourselves as designers, the less we think of ourselves as modernizers. It is from this philosophical or anthropological position on design that I address this audience tonight.

\section{Five advantages of the concept of "design"}

I dare to articulate this odd argument based (very flimsily I agree) on the various undertones of the word "design" itself. It is the weaknesses of this vague concept that give me reason to believe that we can take it as a clear symptom of a sea change in our collective definition of action. The first section of this lecture will review five successive connotations of the concept of design. In the second I will provide an introduction to Peter Sloterdijk's philosophy of design. And finally, I with end with a brief conclusion on how to draw things together, that is, to design.

As a concept, design implies a humility that seems absent from the word "construction" or "building". Because of its historical roots as a mere addition to the "real" practicality, sturdy materiality and functions of daily objects, there is always some modesty in claiming to design something anew. In design there is nothing foundational. It seems to me that to say you plan to design something, does not carry the same risk of hubris as saying one is going to build something. Introducing Prometheus to some other hero of the past as a "designer" would doubtlessly have angered him. Thus, the expansion of the word "design" is an indication (a weak one to be sure) of what could be called a post Promethean theory of action. This theory of action has arisen just at the moment (this is its really interesting feature) when every single thing, every detail of our daily existence, from the way we produce food, to the way we travel, build cars or houses, clone cows, etc is to be, well, redesigned. It is just at the moment where the dimensions of the tasks at hand have been fantastically amplified by the various ecological crises, that a non- or a post- Promethean's sense of what it means to act is taking over public consciousness.

A second and perhaps more important implication of design is an attentiveness to details that is completely lacking in the heroic, Promethean, hubristic dream of action. "Go forward, break radically with the past and the consequences will take care of themselves!" This was the old way - to build, to construct, to destroy, to radically overhaul: "Après moi le déluge!" But that has never been the way of approaching a design project. A mad attention to the details has always been attached to the very definition of design skills. And 'skill' is actually a term that is also attached to design, in the same way that design is associated with the words 'art' and 'craft'. In addition to modesty, there is a sense of skilfulness, craftsmanship and an obsessive attention to detail that make up a key connotation of design. The reason why this is a point worth remarking is because it was unthinkable to connect these features of design with the revolutionary and modernizing urges of the recent past. To the contrary, a careful attention to detail, craft and skill, was precisely what seemed reactionary as this would only have slowed the swift march to progress. The expanding concept of design indicates a deep shift in our emotional make up: at the very moment when the scale of what has to be remade has become infinitely larger (no political 
revolutionary committed to challenging capitalist modes of production has ever considered redesigning the earth's climate), what means to "make" something is also being deeply modified. The modification is so deep that things are no longer "made" or "fabricated", but rather carefully "designed", and if I may use the term, precautionarily designed. It is as though we had to combine the engineering tradition with the precautionary principle; it is as though we had to imagine Prometheus stealing fire from heaven in a cautious way! What is clear is that at this very historical juncture, two absolutely foreign sets of passions (foreign for the modernist ethos that is) are having to be recombined and reconciled.

The third connotation of the word design that seems to me so significant is that when analyzing the design of some artefact the task is unquestionably about meaning - be it symbolic, commercial, or otherwise. Design lends itself to interpretation; it is made to be interpreted in the language of signs. In design, there is always as the French say, un dessein, or in Italian, designo. To be sure, in its weakest form design added only superficial meaning to what was brute matter and efficiency. But as it infiltrated into to more and more levels of the objects, it carried with it a new attention to meaning. Wherever you think of something as being designed, you bring all of the tools, skills and crafts of interpretation to the analysis of that thing. It is thus of great import to witness the depths to which our daily surroundings, our most common artefacts are said to be designed. To think of artefacts in terms of design means conceiving of them less and less as modernist objects, and conceiving of them more and more as "things". To use my language artefacts are becoming conceivable as complex assemblies of contradictory issues (I remind you that this is the etymological meaning of the word "thing" in English -as well as in other European languages). ${ }^{*}$ When things are taken has having been well or badly designed then they no longer appear as matters of fact. So as their appearance as matters of fact weakens, their place among the many matters of concern that are at issue is strengthened.

The transformation of objects into signs has been greatly accelerated by the spread of computers. It is obvious that digitalization has done a lot to expand semiotics to the core of objectivity: when almost every feature of digitalized artefacts is "written down" in codes and software, it is no wonder that hermeneutics have seeped deeper and deeper into the very definition of materiality. If Galileo's book of nature was written in mathematical terms, prodigiously expanding the empire of interpretation and exegesis, this expansion is even truer today when more and more elements of our surroundings are literally and not metaphorically written down in mathematical (or at least in computer) terms. Although the old dichotomy between function and form could be vaguely maintained for a hammer, a locomotive or a chair, it is ridiculous when applied to a mobile phone. Where would you draw the line between form and function? The artefact is composed of writings all the way down! But this is not only true of computerized artefacts and gadgets. It is also true of good old-fashioned materiality: what are nano- or bio-technologies if not the expansion of design to

\footnotetext{
* Latour, B., From Realpolitik to Dingpolitik. How to Make Things Public. An Introduction., in Making Things Public. Atmospheres of Democracy, B. Latour and P. Weibel, Editors. 2005, MIT Press: Cambridge, Mass. p. 1-31.
} 
another level? Those who can make individual atoms write the letters "IBM", those who implant copyright tags into DNA, or who devise nano cars which "race" on four wheels, would certainly consider themselves to be designers. Here again, matter is absorbed into meaning (or rather as contested meaning) in a more and more intimate fashion.

The fourth advantage I see in the word "design" (in addition to its modesty, its attention to detail and the semiotic skills it always carries with it), is that it is never a process that begins from scratch: to design is always to redesign. There is always something that exists first as a given, as an issue, as a problem. Design is a task that follows to make that something more lively, more commercial, more usable, more user's friendly, more acceptable, more sustainable, and so on, depending on the various constraints to which the project has to answer. In other words, there is always something remedial in design. This is the advantage of the "not only... but also" feature although I criticized it above. This split is a weakness to be sure (there is always the temptation of seeing design as an afterthought, as a secondary task, as a less serious one than those of engineering, commerce and science) but it is also an immense advantage when compared to the idea of creation. To design is never to create ex nihilo. It is amusing that creationists in America use the word "intelligent design" as a rough substitute for "God the Creator". They don't seem to realize the tremendous abyss that exists between creating and designing. The most intelligent designers never start from a tabula rasa. God the designer is really a redesigner of something else that was already there - and this is even truer for His Son as well as for the Spirit, who both are sent to redeem what has been botched in the first place... If humanity "has been made (or should I have said designed?) as the image of God", then they too should learn that things are never created but rather carefully and modestly redesigned. It is in that sense that I take the spread of the word design as a clear substitute for revolution and modernization. I do so furthermore, because there is always something slightly superficial in design, something clearly and explicitly transitory, something linked to fashion and thus to shifts in fashions, something tied to tastes and therefore somewhat relative. Designing is the antidote to founding, colonizing, establishing, or breaking with the past. It is an antidote to hubris and to the search for absolute certainty, absolute beginnings, and radical departures.

The fifth and decisive advantage of the concept of design is that it necessarily involves an ethical dimension which is tied into the obvious question of good versus bad design. In the modernist style, this goodness and badness were qualities that matters of fact could not possibly possess. They were supposed to sit there, undisputable, and removed from any normative judgment. This was so much so that their entire purpose was to make the fact/value distinction possible. "We are there whether you like it or not". But it is easy to understand that when you say that something has been "designed", you are not only authorized but forced to ask whether it has been well or badly designed. The spread of design to the inner definitions of things carries with it, not only meaning and hermeneutics, but also morality. More exactly, it is as if materiality and morality were finally coalescing. This is of great importance because if you begin to redesign cities, landscapes, natural parks, societies, as well as genes, brains and chips, no designer will be 
allowed to hide behind the old protection of matters of fact. No designer will be able to claim: "I am just stating what exists", or "I am simply drawing the consequences of the laws of nature", or "I am simply reading the bottom line". By expanding design so that it is relevant everywhere, designers take up the mantle of morality as well. I will come back to this in the conclusion: suffice it to say now that this normative dimension that is intrinsic to design offers a good handle from which to extend the question of design to politics. A politics of matters of facts and of objects has always seemed far fetched; a politics of designed things and issues is somewhat more obvious. If things, or rather Dinge, are gatherings, as Heidegger used to define them, then it is a short step from there to considering all things as the result of an activity called "collaborative design" in Scandinavia. This activity is in fact the very definition of the politics of matters of concern since all designs are "collaborative" designs - even if in some cases the "collaborators" are not all visible, welcomed or willing.

A small parenthesis on our two disciplines: when science and technology studies (STS) scholars began to revisit the old materialist traditions some forty years ago, they too would deeply transformed objects into projects. They too had brought meaning into what was defined as mere "material constraints"; they too had disputed the form versus function argument; transformed matters of fact into complex and contradictory assemblies of conflicting humans and non humans; they too had demonstrated that "artefacts have politics" and that a parliament of things could be assembled. But because of the word "construction" (used especially in the infamous expression "social construction"), they too were divided by the modernist opposition between what was social, symbolic, subjective, lived and what was material, real, objective and factual. No matter how many efforts were made to escape the trap that the modernist constitution has laid in the path of empirical inquiries, science and technology studies has always lurched into it. (Would things have looked better had we talked of "social design" instead of "social construction"? I doubt it). The trap has been nearly impossible to escape. Impossible that is, so long as we remained officially modern. But what is so interesting to me in that in the spread of design, this concept has undergone the same amazing transformations as my own field. STS, that was until a few years back but a small subfield of social (alas, alas, so social!) science, has now received the formidable support of a much larger movement. What was a slightly far fetched and a clearly scandalous claim, namely that there are no objects but only things and disputed assemblages, is now fast becoming common sense. Everything that was conceived of earlier as hard objective undisputable material drives (remember the "irresistible path of progress" "the white heat of technology"?), has now melted into air. Yes, everything that has been designed during the four or five former industrial revolutions has had to be redesigned - including Cornwall. It is the same material world, but now it has to be remade with a completely different notion of what it is to make something. What has gone is mastery - this odd idea of mastery that refused to include the mystery of unintended consequences.

Of course, all five of these dimensions of design as well as the development of STS could be taken as a clear sign of postmodernism, as a quiet and lazy abandonment of the tasks of Promethean modernism. Some diehard modernists 
do think that way, but I don't believe this is the case. As I pointed out earlier, the spread of the word "design" doesn't come at a time when there is less to do; it comes at a time when there is more to do. Infinitely more, since it is the whole fabric of life that is now concerned thanks to the ecological crisis. What no revolution has ever contemplated, namely the remaking of our collective life on earth, is to be carried through with exactly the opposite of revolutionary and modernizing attitudes. This is what renders the spirit of the time so interesting. President Mao was right after all: the revolution has to always be revolutionized. What he did not anticipate is that the new "revolutionary" energy would be taken from the set of attitudes that are hard to come by in revolutionary movements: modesty, care, precautions, skills, crafts, meanings, attention to details, careful conservations, redesign, artificiality, and ever shifting transitory fashions. We have to be radically careful, or carefully radical... What an odd time we are living through.

\section{"Dasein ist Design"}

The best way to sum up the first part of this lecture is by quoting a marvellous pun made by Henk Oosterling: "Dasein ist design". Oosterling is a specialist of the work of Peter Sloterdijk, the great German thinker to whom I will now turn in order to continue this little meditation on the philosophy of design. By taking seriously what Heidegger had only abstractedly meant by Dasein, Sloterdijk has managed to extirpate the Western philosophical tradition from the bifurcated way in which it has always dealt with materiality (always, that is, since the $17^{\text {th }}$ century). This seriousness about Dasein is what makes his philosophy so exciting for people like you who are bombarded with offers to redesign everything from chairs to climates. You cannot indulge anymore into the idea that there are, on the one hand, objective material constraints and, on the other, symbolic, human subjective ones. (Actually, I feel that the organizers of this conference should have invited Sloterdijk to give this keynote instead of me, but my desire to visit a Cornwall I had only "imagined" until now, made me hide this proposition until tonight!)."

The reason for why you should have invited him, is that Sloterdijk, very early on and very literally took on the spread in comprehension and extension of the notion of design. So literally, in fact, that he has been made the Rektor, that is the Dean or Master, of a School in Karlsruhe - the Staatliche Hochschule für Gestaltung (Gestalt being the word here for design). This is a tremendously original art, craft, and philosophy institute (that is housed, by the way, in the same revamped factory as ZKM, the place where I have been fortunate enough to curate the two exhibitions of ICONOGLASH and MAKING THINGS PUBLIC).

When we say that "Dasein is in the world" we usually pass very quickly on the little preposition "in". Not Sloterdijk. In what? he asks, and in where? Are you in a room? In an air conditioned amphitheatre? And if so what sort of air pumps and energy sources keep it up? Are you outside? There is no outside: outside is another inside with another climate control, another thermostat, another air conditioning

\footnotetext{
* Available in English: Sloterdijk, P., Foreword to the Theory of Spheres, in Cosmograms, M. Ohanian and J.C. Royoux, Editors. 2005, Lukas and Sternberg: New York. p. 223-241.
} 
system. Are you in public? Public spaces are spaces too, for goodness sake. They are not different in that respect from private spaces. They are simply organized differently, with different architectures, different entry points, different surveillance systems, different soundscapes. To try to philosophize about what it is to be "thrown into the world" without defining more precisely, more literally (Sloterdijk is first of all a literalist in his use of metaphors) the sort of envelopes into which humans are thrown, would be like trying to kick a cosmonaut into outer space without a spacesuit. Naked humans are as rare as naked cosmonauts. To define humans is to define the envelopes, the life support systems, the Umwelt that make it possible for them to breathe. This is exactly what humanism has always missed. (This is why Habermas became so cross at Sloterdijk and launched a very mean attack against him: naked humans on the one hand, fully equipped humans on life support on the other - of course there was no way for those two German thinkers to agree with one another).

I hope you are beginning to see why Sloterdijk is your philosopher: in the same way as a space suit or a space station is entirely artificially and carefully designed, so are all of the envelopes that constitutes the fragile life supports of humans. (Sloterdijk calls these "spheres", and uses the term, "spherology" to name his endeavour.) Human are to be handled with infinite precaution from the womb (natural or artificial) in which they are grown (Sloterdijk defines philosophy as a kind of obstetrics!) all the way to the place where they survive and die. What is so important in the extended metaphors that Sloterdijk pursues to the bitter end is that they begin to accomplish exactly what I was asking for in the first part of this lecture. How can we reconcile the entirely different sets of emotions, passions and drives triggered by the two alternative Great Narratives of modernity - the one of emancipation (the official story) and the one of attachment (the hidden one)? When you check on your space suit before getting out of the space shuttle, you are radically cautious and cautiously radical... you are painfully aware of how precarious you are, and yet simultaneously, you are completely ready to artificially engineer and to design in obsessive detail what is necessary to survive. Whereas modernist or anti-modernist philosophies of history are always considering only one narrative (that of progress or the failure of progress), Sloterdijk is the rare thinker who shows how the stories of both emancipation and of attachment are a single story. This unification is possible provided that you deeply modify what it is to be "in the world": the cosmonaut is emancipated from gravity because he or she never lives one fraction of a second outside of his or her life supports. To be emancipated and to be attached are two incarnations of the same event, provided you draw your attention to how artificial atmospheres are well or badly designed.

The concept that is key for reconciling those two sets of passions and for inventing this strange role of a precautionary Prometheus, is that of explicitation. Explicitation is a consequence of the concept of envelopes. The envelope is a term that will surely draw the attention of architects and designers: we are enveloped, entangled, surrounded; we are never outside without having recreated another more artificial, more fragile, more engineered envelope. We move from envelopes to envelopes, from folds to folds, never from one private sphere to the Great Outside. 
Modernism, in the hands of Sloterdijk is no longer a concept. It is a place, a design, a style. It is a very specific type of architecture to which the whole second volume of SPHÄREN is dedicated: that of Globes. A modernist is someone who lives under a vast dome, and who sees things as though sitting under a huge architecture, the Globe of Science, the globe of Reason, the globe of Politics. For the modernist, the humanist is the one who reads a book under a lamp or who sits clothed in some sort of Roman toga on the stairs of a huge amphitheatre under the painted fresco of some immense dome... except that in the modernist architecture, the life supports necessary for this Dome or this Globe to be sustainable have not been explicitated. A modernist takes for granted that there will always be air, space, water, heat, for the development of his or her "global view". But there is nothing global in globalization. Global is always a lot of globaloney, a lot of hot air. And of course, blowing hot air also requires a mechanism of some sort, a pump, a hairdryer - a designed hairdryer! What happened in the second half of the last century is that modernism disappeared in the exact measure where the life supports were made more explicit, one after the next. Ecological crisis, in such a view, are the slow and painful realization that there is no outside anymore. It means that none of the elements necessary to support life can be taken for granted. To live under a huge inflated Globe you need a powerful air conditioning system and powerful pumps to keep it inflated. Yes, modernist Globes have been deflated; modernism's fate has been somewhat the same as that of those dirigibles, like the Zeppelin or the Hindenburg.

So you see, what was called the "modernist style" in history of design should now be given a much more profound signification and a much longer life span. The very ways in which things have presented themselves as matters of fact which are now visible as a style - and a style that is changing under our very eyes. The aesthetics of matters of fact have always been precisely that: a historically situated aesthetics, a way to light objects, to frame them, to present them, to situate the gaze of the viewers, to design the interiors in which they are presented - and of course the politics with which they are (they were) so strongly associated.*

What I find so important in the notion of explicitation, of folding envelopes into envelopes, is that it is a powerful way of retrieving science and technology by completely modifying what is meant by a sustainable artificial life. It is really in that sense, that Sloterdijk is THE philosopher of design. If earlier I have been correct in defining the five reasons why the notion of design was such a powerful substitute to the notion of making, building and constructing, explicitation might allow us to understand that it is possible to rematerialize without importing with the notion of 'matter' the whole modernist baggage of 'matters of fact'. This is exactly what Sloterdijk does. No contemporary philosopher is more interested in materiality, in engineering, in biotechnology, in design proper, in contemporary arts, and in science more generally. Yet when he deals with materialities it is not as if these were so many matters of fact that would inject indisputable natural necessity as the final word in some social or symbolic questions. Instead, when he adds materiality to a site he is rendering another fragile envelope into which we

* Latour, B., What is the Style of Matters of Concern? Two Lectures on Empirical Philosophy. Booklet of the Department of Philosophy Amsterdam, 2005 (accessible on the web at bruno-latour.fr xx). 
are even more entangled, explicit. This entanglement is as relevant for the envelopes of biotechnology as it is for space stations.

This is exactly the reason why Habermas could not accept Sloterdijk's argument. For a good old modernist humanist, when someone begins to talk about life support, about the necessary conditions to "cultivate human beings", about the air-conditioning to have them breathe safely, this is a tantamount to a plea for an Orwellian world, for eugenism. What Habermas has entirely missed, however, is that when humanists accuse people of "treating humans like objects", they are thoroughly unaware that they are treating objects unfairly. A humanist cannot imagine that objects may be things, that matters of facts might be matters of concern, that the whole language of science and engineering might be portrayed as anything other than the boring carriers of the indisputable necessities that modernism has rendered popular. Humanists are concerned only about humans; the rest, for them, is mere materiality or cold objectivity. But Sloterdijk is not treating humans matter of factually as humanists claim. Rather, he treats both humans and non humans as "matters of grave and careful concerns". By treating human life supports as matters of concern, we pile concerns over concerns, we fold, we envelop, we embed humans into more and more elements that have been carefully explicitated, protected, conserved and maintained (immunology being, according to Sloterdijk, the great philosophy of biology).

This little shift in the definition of matter modifies everything. It allows practitioners to reuse all of the notions of materiality and of artificiality by freeing them from the restrictions imposed by the older style of modernist matters of fact. In other words, we can have science and technology without implying naturalization. Not only has nature disappeared as the outside of human action (this has become common wisdom by now); not only has "natural" become a synonym of "carefully managed", "skilfully staged", "artificially maintained", "cleverly designed" (this is true especially of so called "natural" parks or "organic foods"); but the very idea that to bring the knowledge of scientists and engineers to bear on a question is to necessarily resort to the unquestionable laws of nature, is also becoming obsolete. Bringing in scientists and engineers is quickly becoming another way of asking: "How can it be better redesigned?" The bricolage and tinkering elements always associated with design have taken over nature. Actually, they are inherent in nature if we take Darwinian ways as a clever form of bricolage, of "intelligent design"... albeit a blind one.

It is somewhat understandable that when Sloterdijk raised the question of how humans could be "designed", that is, artificially nurtured, this invokes the old phantasm of eugenic manipulations. But the similarities between these two projects prove to be completely superficial when submitted to a close examination. They are similar only in the same way that two trains can both be moving ahead even though they are at an intersection that will lead them toward completely different destinations. Habermas missed the switch, the bifurcation that is so important for us to locate. Yes humans have to be artificially made and remade, but everything depends on what you mean by artificial and even more deeply by what you mean by "making". We have returned to Prometheus and to the question of Creation. Are we able to be the God of intelligent design? This is the 
heart of the matter. This is why it is so important to talk of design and not of construction, creation or of fabrication. To design something as I indicated earlier, allows us to raise not only the semiotic question of meaning but also the normative question of good and bad design. This is true of DNA manipulation, as well as of climate control, gadgets, fashion, cities or natural landscapes, a perfect case of design from beginning to end. Artificiality is our destiny, but it does not mean accepting the modernist definition of an artefact as the invasion of matters of fact over the softer flesh of human frailty forever. To put it even differently by alluding to another line of more fashionable thought: there is nothing necessarily post human in enveloping, folding, veiling humans into their life supports. Humanists as well as post-humanists seem to have no other repertory for speaking of science and technology other than the modernist idiom of matters of fact.

The great importance of Sloterdijk's philosophy (and I think the major interest of a designer's way of looking at things) is that it offers another idiom. The idiom of matters of concern reclaims matter, matters and materiality and renders them into something that can and must be carefully redesigned. This might be far from the humanists' limited view of what humans are, but it is every bit as removed from the post human dreams of cyborgs. What is clear is that the collective definition of what artificial life supports are supposed to be becomes the key site of politically minded investigation. Nothing much is left of the scenography of the modernist theory of action: no male hubris, no mastery, no appeal to the outside, no dream of expatriation in an outside space which would not require any life support of any sort, no nature, no grand gesture of radical departure - and yet still the necessity of redoing everything once again in a strange combination of conservation and innovation that is unprecedented in the short history of modernism. Will Prometheus ever be cautious enough to redesign the planet?

I hope I have not been too far off the mark by proposing (out of ignorance, surely) these few steps toward a philosophy of design or by introducing Sloterdijk as its main contributor. I wish to conclude by offering a challenge to the specialists of the history of design assembled here. When I said earlier that there is something inherently normative in design because of the necessary follow up question, "Is it well or badly designed?", I also mentioned that this was a good handle for bringing in the question of politics. If the whole fabric of our earthly existence has to be redesigned in excruciating details; if for each detail the question of good and bad has to be raised; if every aspect has become a disputed matter of concern and can no longer be stabilized as an indisputable matter of fact; then we are obviously entering into a completely new political territory. As every one of you knows too well, it is the perverse character of all ecological questions that they branch out in all sort of counterintuitive ways. It is probably of ecology that St Paul was talking when he said: "I don't do the good I wish to do and I do the bad that I hate". Political ecology is bringing political difficulty to the square. For according to this marvellous rather Paulinian quote of de Gaulle: "If of the good only good would ensue, and if of bad only bad ensued, government would be rather simple: a village parson could do it". 
Let me raise the question of design, taken literally in the etymological sense of drawing or rather of "drawing together". How can we draw together matters of concern so as to offer to political disputes an overview, or at least a view, of the difficulties that will entangle us every time we must modify the practical details of our material existence? We know that whenever we prepare to change our fixtures from incandescent to low energy light bulbs, to pay our carbon expenses, to introduce wind farms, to reintroduce the wolf to the Alps, or to develop corn based fuel, immediately, some controversy will be ignited that turns our best intentions into hell. And we are no longer able to stop the controversies by stating the undisputable facts of the matter because facts are constantly disputed. Fine, unintended consequences are now on everyone's mind, Prometheus braces himself for the worse.

Now here is the challenge: In its long history, design practice has done a marvellous job of inventing the practical skills for drawing objects, from architectural drawing, mechanic blueprints, scale models, prototyping etc. But what has always been missing from those marvellous drawings (designs in the literal sense) are an impression of the controversies and the many contradicting stake holders that are born within with these. In other words, you in design as well as we in science and technology studies may insist that objects are always assemblies, "gatherings" in Heidegger's meaning of the word, or things and Dinge, and yet, four hundred years after the invention of perspective drawing, three hundred years after projective geometry, fifty years after the development of CAD computer screens, we are still utterly unable to draw together, to simulate, to materialize, to approximate, to fully model to scale, what a thing in all of its complexity, is. We know how to draw, to simulate, to materialize, to zoom in and out on objects; we know how to make them move in 3-D space, to have them sail through the computerized virtual res extensa, to mark them with a great number of data points, etc. Yet we are perfectly aware that the space in which those objects seem to move so effortlessly is the most utopian (or rather atopic) of spaces. It these are the least realistic spaces of circulation ever imagined. They are spaces that do not even fit with the ways in which architects, engineers, designers draw and modify blueprints, nor with the process through which they direct fabrication on the factory floor or manipulate scale models. To use some more German: we know how to draw Gegenstand but we have no clue what it is to draw Ding. I once asked one of the greatest historians of technology to send me what he considered his best drawing of the marvellously complex history of mechanisms he has been writing about for so long. He sent me some doodle which I would not have dared showing to my first year students as an example of what a thing is. How could this doodle be compared to the comfortable and effortless manner in which objects float through the so called "Euclidian space" of a CAD design or to the ways in which I can visit Falmouth before I arrive there through the apparently smooth travel of Google Earth?

I know this is a meeting on the history of design, but what would be the use of studying design history, if not for the purposes of providing a scheme for its future? There is much to suggest that the whole history of technical drawing and of scientific visualizations more broadly conceived has been one of the main driving 
forces for the development of science and technology in its modernist version. It is more than likely that the same will be true for the development of science and technology, once freed from its modernist limitation. However, what history also shows is that we are a long way from being able to provide for things, that is for matters of concern, a visual, publicly inspectable space that is as remotely as rich, at least as easy to handle, and as codified as what has been done over four centuries for objects conceived of as matters of fact. As long as this lacuna remains there will be no way for design to ease modernism out of its historical dead end. To imagine that a political ecology of the magnitude being anticipated by all of the experts can be carried out without new innovative tools is to court disaster. New innovation will be absolutely necessary if we are to adequately represent the conflicting natures of all the things that are to be designed. (I take here the verb "to represent" here in the largest sense, including artistic, scientific and political representation techniques).

So here is the question I wish to raise to designers: where are the visualization tools that allow the contradictory and controversial nature of matters of concern to be represented? A common mistake (a very post-modernist one) is to believe that this goal will have been reached once the "linear", "objectified", and "reified" modernist view has been scattered through multiple view points and heterogeneous make shift assemblages. However, breaking down the tyranny of the modernist point of view will lead nowhere since we have never been modern. Critique, deconstruction and iconoclasm, once again, will simply not do the job of finding an alternative design. What is needed instead are tools that capture what have always been the hidden practices of modernist innovations: objects have always been projects; matters of fact have always been matters of concern. The tools we need to grasp these hidden practices will teach us just as much as the old aesthetics of matters of fact - and then again much more. Let me be clear - I am not advocating another CAD design for Prometheus. What I am pressing for is a means for drawing things together - gods, non humans and mortals included. Why should this prove to be an impossible task? Why can the powerful visual vocabulary that has been devised in the past by generations of artists, engineers, designers, philosophers, artisans and activists for matters of fact, not be devised (I hesitate to say restyled) for matters of concern? 